\title{
Rehabilitation in the aquatic environment
}

\author{
Magdalena Pieniążek ${ }_{\text {ABCDEFG }}^{1}$ \\ ${ }^{1}$ Collegium Medicum, Jagiellonian University, Cracow, Poland
}

\begin{abstract}
An increasing number of individuals with different types of musculoskeletal dysfunction results in growing significance of rehabilitation in the aquatic environment as an important alternative to classic rehabilitation. The specific physicochemical features of water enable treatment as well as a wide range of physical therapy, particularly in such diseases where rehabilitation can only be performed in this environment due to strain. The article presents the basic elements of rehabilitation in the aquatic environment combined with its properties, effects of specific water features on efficiency and comfort of treatment as well as reasons why this type of rehabilitation develops slower than the current needs for such services.Key words: Ebola, health risk, disease
\end{abstract}

Key words: rehabilitation, aquatic environment, physical properties of water.

\section{Introduction}

The history of aquatic environment use by man reveals that this environment has a large rehabilitation potential enabling therapy of severe traumas and chronic diseases. Despite many positive aspects and increasingly high needs, this form of rehabilitation is not sufficiently popularised. Even the oldest historical sources show that water received recognition as it supports the healing process and enhances strength, hence is used for the treatment of many diseases and traumas. Long-term attempts, errors and scientific experiments as well as habits of healing with water resulted in the evolution of forms and nature of this therapy [1]. Among numerous factors, biological effects of water on the human body are essential. The effects can be immediate or delayed and enable effective work with patients affected by various diseases [2]. The water environment facilitates the patients with impaired motor efficiency to perform exercises unaided. This is associated with buoyancy, which is different in this environment and the land environment. However, it should be remembered that water variously affects body systems; therefore, contraindications for rehabilitation in water should always be carefully checked [3]. Moreover, both hydrotherapy and recreation in water carry the risk of severe accidents and due to such specific conditions each physiotherapist is trained how to prevent dangerous situations and administer prompt assistance, if need be. The issue in question is particularly important in large water areas, mainly unguarded (lakes, rivers), where dangerous incidents occur most commonly.
Use of physical properties of water in hydrotherapy

A relevant feature of aquatic environment is heterogeneity of its physical properties, which differently affect the efficacy of rehabilitation. In many cases, the properties favourable for the treatment of a particular disease can be harmful in other ailments. The above can be seen in hydrotherapy, a branch of physiotherapy [4]. The method involves external use of water in its various forms: liquid, solid and gaseous. The basis of therapeutic effects of this method is appropriate temperature, required water pressure and its chemical composition suitably used for a particular form of therapy. Only the choice of water of proper physicochemical features ensures the efficacy of rehabilitation of dysfunction and improvement of many other body functions. Hydrotherapy increases metabolism, improves heart action and cardiovascular functions, increases tissue blood supply and lymph flow, removes waste metabolites, increases blood oxygenation, reduces skeletomuscular static load, eliminates toxins and bacteria through the skin, enhances general immunity and shortens the time of post-effort reduced efficiency. Such a wide range of effects indicates high usefulness of hydrotherapy in restoring the body's general health state [5]. However, many outpatient clinics do not use hydrotherapy due to high costs of water and energy and the number of ambulatory care centres of hydrotherapy has decreased. On the other hand, the development of hydrotherapy can be observed in health-resorts, where its various available forms are used. 


\section{Therapeutic significance of temperature}

Besides the physical properties of water, which significantly affect the human body, water temperature is crucial for providing the desired outcomes of hydrotherapy. Temperature can substantially suppress or stimulate the body processes and reactions to various stimuli. Cold baths stimulate the body whereas heat calms down and induces drowsiness. Warm baths are applied relatively rarely, although their use is not excluded as by elevating the body temperature they help in the treatment of many rheumatic diseases of joints, muscles and nerves.

For practical reasons and in accordance with physiology, it has been assumed that water, which temperature is higher than body temperature can be warm, very warm, hot and very hot, unpleasantly hot and unbearably hot. The theoretical limit of tolerance for man is water of $50^{\circ} \mathrm{C}$, in practice - about $45-46^{\circ} \mathrm{C}$ yet only in short-term exposures. Such high temperatures are not used in hydrotherapy. Water of the temperature lower than the body temperature can be neutral, cold and very cold. The conventional classification of bath temperatures is presented in table 1 .

Table.1. Perceived and real water temperature

\begin{tabular}{|c|c|}
\hline Perceived water temperature & $\begin{array}{c}\text { Real water tempera- } \\
\text { ture }\end{array}$ \\
\hline very cold & $10-15^{\circ} \mathrm{C}$ \\
\hline cold & $15-30^{\circ} \mathrm{C}$ \\
\hline neutral & $35-36^{\circ} \mathrm{C}$ \\
\hline warm & $37-38^{\circ} \mathrm{C}$ \\
\hline very warm & $39-40^{\circ} \mathrm{C}$ \\
\hline hot & $40-45^{\circ} \mathrm{C}$ \\
\hline very hot & $45-50^{\circ} \mathrm{C}$ \\
\hline
\end{tabular}

Considering the temperature factor, it should be remembered that water and air have different thermal conductivity and heat capacity. Therefore, under the same temperature ranges, individuals experience different thermal sensations in these environments, e.g. $23-30^{\circ} \mathrm{C}$ can be felt as warm or hot air while the same temperature of water as neutral or even cold.

The effect of temperature on vital function is best illustrated by an example of an individual who fell into cold seawater, which resulted in a decrease in body temperature to the life-threatening level.

\section{Buoyancy in water bath}

An extremely important mechanical factor of therapeutically effects in water baths is buoyancy, which force is directed horizontally upwards, hence in the direction opposite to the force of gravity. Therefore, the resultant forces affecting individuals immersed in water are lower than their weight in air and dependent on the depth of immersion.

Due to this law, muscles relax and almost all movements can be easily performed. Relaxed muscles can be subjected to effective exercises under markedly lower strain. Moreover, joints are unweighted and full-range mobility movements are easier carried out. Thanks to the above properties, therapy in water can be applied in pareses, contractures or reduced joint mobility.

The depth of immersion is relevant. An individual immersed in water at the level of pubic symphysis, seemingly "loses" about $40 \%$ of body weight in air. Further immersion to the umbilical level causes a reduction by about $50 \%$. The depth reaching the lower sternum can reduce the body weight by $60-70 \%$, depending on the position of hands - above the head or along the trunk. The percentage distribution of apparent weight loss in individuals immersed in water is presented in fig.1.

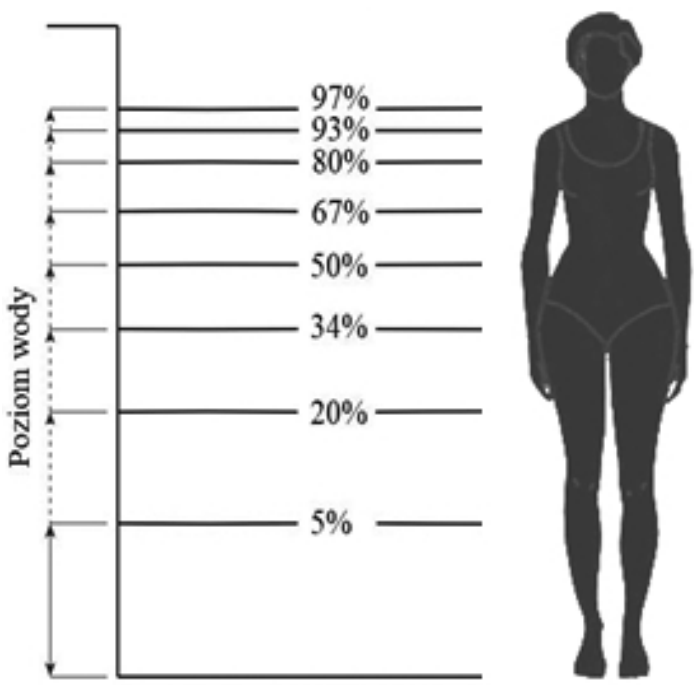

Fig. 1. Percentage distribution of apparent weight loss during gradual immersion in water [5]

The most important asset of this form of rehabilitation is a maximum reduction of lower limb load limitations, which enables rehabilitation in deep water, where exceeding such limitations is practically impossible [6]. 


\section{Hydrostatic pressure}

The pressure exerted by water column, dependent on its height, is a potent mechanical stimulus affecting the body immersed in water. Its lowest strength is observed in partial baths whereas the highest one in complete baths. In the latter, hydrostatic pressure induces increased intra-abdominal pressure, compression of soft tissues, hindered inspiration and facilitated expiration. It also results in blood shift in the venous part from the heart periphery, which leads to filling of jugular veins, increased heart volume, increased central venous pressure and hormonal and reflex-mediated triggering of diuresis (associated with excretion of urine). Hydrostatic pressures according to immersion depths are listed in fig.2. se adverse effects are eliminated by compensatory and regulatory body mechanisms.

During the therapy carried out as a series of procedures, the mechanisms are identically stimulated and train or improve the organ functions; thanks to that, they can counteract disease-associated changes. Noteworthy, the pharmaceuticals used to date do not show similar effects.

The hydrotherapy devices presently available are programmed for minimum water and energy consumption, which reduces the cost of therapy. It is hoped that in the nearest future, increasing numbers of patients will undergo hydrotherapy to reduce the negative effects of civilization on the human body, as the biggest value of hydrotherapy results from the rule "prevention is better than tre-

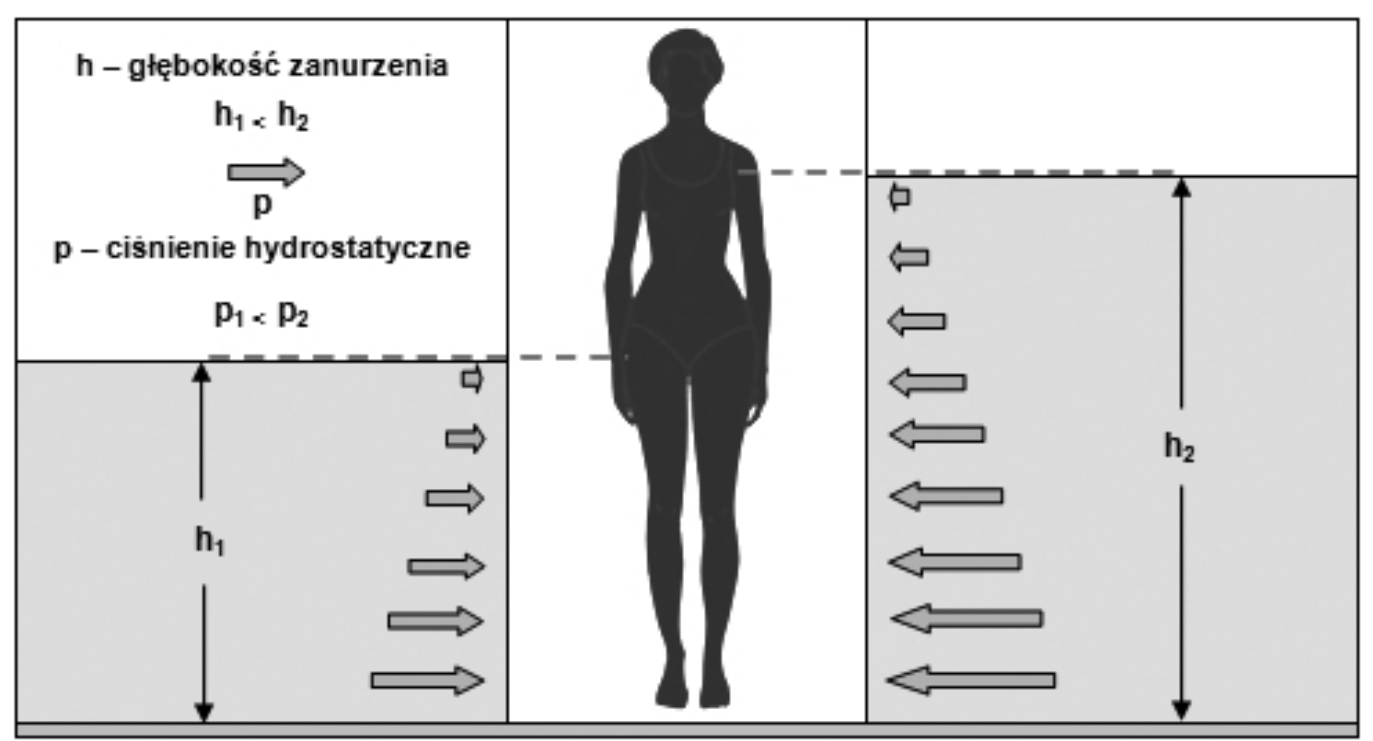

Fig. 2. Correlation of hydrostatic pressure and depth of water immersion

All the above biological effects result from basic laws of hydrodynamics. Therefore, they should be understood in order to adequately plan and carry out the therapy with the maximum use of water properties.

\section{EFFECTS OF WATER ON INDIVIDUAL BODY SYSTEMS}

Hydrotherapeutic procedures have beneficial effects during therapy of immune and rheumatic diseases. Moreover, they increase the non-specific response (congenital, genetically-conditioned) to diseases and favourably affect some allergic conditions. In their initial stages, hydrotherapeutic procedures cause changes in organ functions, who- atment". Detailed analysis of water-induced changes in individual human organ systems is presented in table 2. 
Table 2. Changes in the individual organ systems in aquatic environment [7]

\begin{tabular}{|c|c|c|}
\hline & Systems & $\begin{array}{l}\text { Characteristics of basic changes in indivi- } \\
\text { dual organ systems induced by therapy in } \\
\text { aquatic environment }\end{array}$ \\
\hline & Cardiovascular & $\begin{array}{l}\text { Depending on water temperature, vaso- } \\
\text { motor changes can involve constriction } \\
\text { or dilation of blood vessels- arteries, veins } \\
\text { and capillaries, which results in changes } \\
\text { in blood flow volume, higher on dilation } \\
\text { and lower on constriction. Vasomotor } \\
\text { changes that developed locally can spread } \\
\text { to other skin regions or even remote areas } \\
\text { in the other body parts due to consensual } \\
\text { reflexes. The Dastre-Morat law states that } \\
\text { blood vessels located deeper and exposed } \\
\text { to thermal stimuli, act differently than skin } \\
\text { blood vessels. In practice, when skin blo- } \\
\text { od vessels dilate, vessels of internal organs } \\
\text { constrict. An exception regards blood ves- } \\
\text { sels of the brain, spleen, kidneys and coro- } \\
\text { nary vessels, which act as skin vessels. }\end{array}$ \\
\hline & Respiratory & $\begin{array}{l}\text { When water of neutral temperature in } \\
\text { complete baths reaches the umbilical level, } \\
\text { respiratory changes develop, i.e. minute } \\
\text { lung ventilation decreases due to decre- } \\
\text { ased tidal volume Minute lung ventilation } \\
\text { in warm baths is 3-4 times higher; in hot } \\
\text { baths - can be slightly lower, compared to } \\
\text { warm baths. Resultant hyperventilation } \\
\text { causes a reduction in the content of carbon } \\
\text { dioxide in blood and can lead to alkalosis } \\
\text { manifesting in excessive mental excitation } \\
\text { and confusion. In their initial stage, cold } \\
\text { baths increase minute ventilation of lungs, } \\
\text { breathing is irregular and shallow. Cool } \\
\text { baths markedly increase minute lung ven- } \\
\text { tilation at increased tidal volume, due to } \\
\text { the thermoregulatory mechanism, which } \\
\text { generates warmth in the body. }\end{array}$ \\
\hline & $\begin{array}{l}\text { Gastrointe- } \\
\text { stinal and } \\
\text { metabolic }\end{array}$ & $\begin{array}{l}\text { In their initial stages, warm baths stimulate } \\
\text { the secretion of gastric juice and peristal- } \\
\text { tic movements, which is followed by their } \\
\text { inhibition. Moreover, appetite is decre- } \\
\text { ased. Cold baths increase the secretion of } \\
\text { gastric juice and peristaltic movements as } \\
\text { well as appetite. Metabolic processes (re- } \\
\text { garding mainly carbohydrates and fats) } \\
\text { in cool and cold water are quicker due to } \\
\text { increased thermal energy demands of the } \\
\text { body. In warm baths with the temperature } \\
\text { only slightly exceeding the body tempera- } \\
\text { ture, blood vessels dilate, resulting in war- } \\
\text { mth consumption by the body. There is no } \\
\text { evaporation; therefore, perspiration under } \\
\text { such conditions is not capable of equalising } \\
\text { the difference in temperatures. }\end{array}$ \\
\hline & $\begin{array}{l}\text { Nervous and } \\
\text { muscular }\end{array}$ & $\begin{array}{l}\text { Thanks to reflexes, the central nervous sys- } \\
\text { tem (CNS) plays the most important role in } \\
\text { the development of reactions to hydrothera- } \\
\text { peutic stimuli. Short, warm baths stimulate } \\
\text { the CNS, while long baths have inhibitory } \\
\text { effects, reducing pain, decreasing muscle } \\
\text { tone, and acting hypnotically. Cold baths } \\
\text { stimulate the CNS, improve general well-be- } \\
\text { ing and enhance readiness for exercises and } \\
\text { physical efforts. Unlike warm baths, cold } \\
\text { baths increase the sensations of pain and } \\
\text { tone of the superficial muscle groups. }\end{array}$ \\
\hline
\end{tabular}

It should be remembered that water is not and should be the only therapeutic measure; nevertheless, it strengthens the body and mind, which is essential for the therapy of individual diseases.

\section{Rehabilitation in aquatic environment}

The human body undergoing hydrotherapy is exposed to all energy vectors, whose carrier is water. The appropriately prepared rehabilitation in the aquatic environment ensures extensive effects of stimuli on the body and enables increased ranges of physical activity. The essential factors involved in this process are temperature, hydrostatic pressure and hydrodynamic pressure in water stream. Generally, the above factors act simultaneously and unidirectionally; however, in some cases they can act in opposition. An example is warm water, which dilates blood vessels while hydrostatic pressure constricts them. Appropriate adjustment of water temperature for individual forms of rehabilitation is presented in table 3 .

Table 3. Ranges of temperatures used during individual forms of rehabilitation [2]

\begin{tabular}{|c|c|c|c|c|c|}
\hline \multirow[t]{2}{*}{ Activity } & \multicolumn{5}{|c|}{ Water temperature } \\
\hline & cold & cool & neutral & warm & hot \\
\hline $\begin{array}{l}\text { Post-effort recupe- } \\
\text { ration }\end{array}$ & $\bullet$ & & & & \\
\hline Alternating baths & $\bullet$ & & & $\downarrow$ & $\downarrow$ \\
\hline Energy exercises & & $\downarrow$ & & & \\
\hline $\begin{array}{l}\text { Exercises in dege- } \\
\text { nerative diseases of } \\
\text { joints }\end{array}$ & & & $\bullet$ & & \\
\hline $\begin{array}{l}\text { Classic therapy in } \\
\text { water }\end{array}$ & & & $\bullet$ & & \\
\hline $\begin{array}{l}\text { Cardiac rehabili- } \\
\text { tation }\end{array}$ & & & $\bullet$ & & \\
\hline Exercises in MS & & $\bullet$ & & & \\
\hline $\begin{array}{l}\text { Exercises in spine } \\
\text { injuries }\end{array}$ & & & $\bullet$ & & \\
\hline $\begin{array}{l}\text { Exercises in Parkin- } \\
\text { son's disease }\end{array}$ & & & $\bullet$ & & \\
\hline Relaxation & & & & 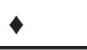 & $\bullet$ \\
\hline
\end{tabular}

Thanks to its beneficial influence on the body, therapy in water accelerates the treatment process, improves the immune system function, exerts relaxing effects and eliminates the consequences of stress. All the above induces calmness and peacefulness as well as positive attitudes towards life, improves memory and concentration [8]. In the aquatic environment, the body positions assu- 
med can favourably affect the psychomotor development. Supine positions are most commonly used, but multi-plane and lateral recumbent positions are also applied [9]. Exercises in water minimally burden the skeleton-articular system, thus can be recommended as a form of activity for individuals with spinal pain-associated problems, advanced osteoporosis, or injuries to joints and bones. Physiotherapists should have professional knowledge about the effects of biological therapy, thanks to which they can prepare the optimal schedule of treatment, suitably modifying temperatures, depth of immersion and duration of procedures [2]. This is the basis of choosing the most appropriate form of physical activity for a particular patient. Depending on patient's condition and disease, the techniques can be tailored in such a way as to ensure safety, satisfaction and best outcomes (table 4).

Table.4. Selected forms of physical activity used during rehabilitation [2]

\begin{tabular}{|c|c|c|c|c|c|c|c|c|c|c|}
\hline Techniques & 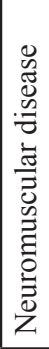 & 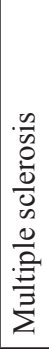 & 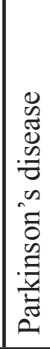 & 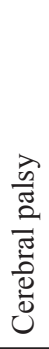 & 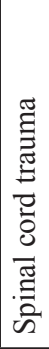 & 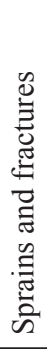 & $\begin{array}{l} \\
\\
\text {. } \\
\text { त्र } \\
0 \\
0 \\
0\end{array}$ & 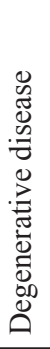 & $\begin{array}{l} \\
\text { Dे } \\
\text { స్ } \\
\text { D. } \\
0 \\
0\end{array}$ & 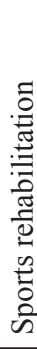 \\
\hline $\begin{array}{l}\text { One-to-one } \\
\text { therapy }\end{array}$ & 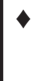 & $\bullet$ & $\bullet$ & $\bullet$ & $\bullet$ & $\bullet$ & & & & - \\
\hline $\begin{array}{l}\text { Respiratory } \\
\text { training }\end{array}$ & 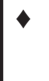 & $\bullet$ & & $\bullet$ & $\bullet$ & & & & & \\
\hline $\begin{array}{l}\text { Spine stabi- } \\
\text { lisation in } \\
\text { water }\end{array}$ & & & & & & 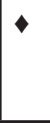 & & & • & - \\
\hline $\begin{array}{l}\text { Mobilisation } \\
\text { of joints }\end{array}$ & & & & & $\bullet$ & 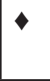 & & & & $\bullet$ \\
\hline Watsu & 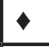 & $\bullet$ & & 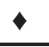 & 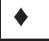 & & & & & \\
\hline $\begin{array}{l}\text { Group thera- } \\
\text { py in warm } \\
\text { water }\end{array}$ & $\bullet$ & & & & & & $\bullet$ & $\bullet$ & & \\
\hline $\begin{array}{l}\text { Balance tra- } \\
\text { ining }\end{array}$ & & $\bullet$ & $\bullet$ & & & & & & & \\
\hline Ai Chi & & & $\bullet$ & & & $\checkmark$ & & $\bullet$ & & \\
\hline Yogalates & & & 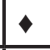 & & & & $\bullet$ & 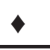 & 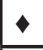 & \\
\hline $\begin{array}{l}\text { Aqua aero- } \\
\text { bics }\end{array}$ & & & & & & & $\bullet$ & $\bullet$ & $\bullet$ & \\
\hline Aqua jogging & & & & & & & 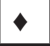 & & $\diamond$ & \\
\hline
\end{tabular}

The most common forms of therapy include the one-to-one method, in which the physiotherapist works individually with the patient, and group therapy. The use of these forms enables to introduce the techniques of respiratory and balance training, stabilisation of the spine and mobilisation of joints. The technique, which is less known, is Ai Chi - i.e. a combination of Tai Chi [10], Qi gong [11] and Watsu. It involves exercises of the arms, legs and trunk performed with a very slow speed as well as deep and peaceful breathing. Water should be warm and reach the arms. Yogalates is a combination of Yoga and Pilates. Although the exercises are not carried out on mats in a gymnasium, the goal is similar, i.e. strengthening of postural muscles, relaxation and stretching. Another method is aqua-aerobic, frequently chosen as a form of recreation and not only rehabilitation. Aqua jogging is still a novelty in Poland, which is associated with the necessity to use burdensome equipment and higher popularity of aqua-aerobic [12]. In aqua jogging, a special belt is required, which keeps the silhouette in an appropriate position and dumb-bells. In many cases, specially designed shoes are also used.

A less known method of therapy is Watsu, i.e. a combination of exercises, mobilisation, stretching, and compressions of Shiatsu points in warm water. The water temperature should be $33-35^{\circ} \mathrm{C}$ as it has a large effect on deep relaxation, which is the outcome of therapy. Qualified therapists chose proper methods of sessions as to make patients feel safe and relaxed. Watsu involves a variety of exercises and sequences. The initial positions and movements are simple and are followed by more complex ones. Each session lasts 30 minutes to one hour. After the conversation with the therapist the patient lies down on the water surface and closes hi/her eyes. To achieve the desirable effects, full relaxation is needed. Exercises are gradually intensified, with short intervals during which the patient remains motionless. The therapist chooses such positions to work each body part. In some of them, due to the required access to a given body part, the patient and therapist are in very close contact, which can be uncomfortable. Therefore, in some cases, the activities are modified or some sequences abandoned. The patient can breathe freely, as he/she is over the water surface throughout the exercises. This form of therapy reduces muscle tone, joint pain, tiredness, improves the joint mobility, quality of sleep and metabolic 
processes. The therapy in question is recommended for rheumatic and degenerative diseases but also for exhausted patients, depression and sportsmen. The general assessment reveals that patients prefer the activities in which physiotherapists are in continuous and direct contact with patients, are interested in the problems that can occur and attempt to improve the rehabilitation process. Since clients search for such characteristics, Watsu is becoming extremely popular [13].

Professionalism of rehabilitation and therapists is strictly conditioned by the knowledge of hindering contraindications (table 5).

Table 5. Absolute and relative contraindications for rehabilitation in water [8]

\begin{tabular}{|c|c|c|c|}
\hline $\begin{array}{l}\text { Absolute con- } \\
\text { traindications }\end{array}$ & $\begin{array}{l}\text { Relative con- } \\
\text { traindications }\end{array}$ & & \\
\hline . & high fever & & \\
\hline • & $\begin{array}{l}\text { active arthri- } \\
\text { tis }\end{array}$ & & \\
\hline • & open wounds & & \\
\hline • & skin lesions & & \\
\hline • & incontinence & & \\
\hline - & diarrhoea & & \\
\hline • & tuberculosis & & \\
\hline • & $\begin{array}{l}\text { unstable an- } \\
\text { gina pectoris }\end{array}$ & & \\
\hline • & $\begin{array}{l}\text { uncontrolled } \\
\text { epilepsy }\end{array}$ & - & pregnancy \\
\hline • & $\begin{array}{l}\text { o n g o i } \mathrm{g} \\
\text { dialysis }\end{array}$ & & \\
\hline • & $\begin{array}{l}\text { ongoing che- } \\
\text { motherapy }\end{array}$ & & \\
\hline • & hydrophobia & & \\
\hline - & $\begin{array}{l}\text { mental retar- } \\
\text { dation hinde- } \\
\text { ring contact }\end{array}$ & & \\
\hline • & $\begin{array}{l}\text { hypersensiti- } \\
\text { vity to chlo- } \\
\text { rine }\end{array}$ & & \\
\hline • & $\begin{array}{l}\text { post-operati- } \\
\text { ve limitations } \\
\text { regarding po- } \\
\text { sition/ move- } \\
\text { ments }\end{array}$ & & \\
\hline
\end{tabular}

The range of contraindications shows that rehabilitation in water should be continuously supervised by the medical personnel. During hydrotherapy, special attention should be paid to the possibility of drowning, e.g. during fainting. This danger can be reduced by working with small groups and using the one-to-one method, yet it can be eliminated. Moreover, the temperature of water should be continuously monitored to avoid overheating. General safety discipline is crucial. Both therapists and patients should wear anti-skidding shoes and the swimming-pool environment should be dry. Furthermore, swimming-pool traffic should be controlled; individuals who are not involved in rehabilitation exercises should not stay in the swimming pool. Patients ought to follow the personal hygiene rules and disinfect their feet before immersing in the swimming pool to avoid the spread of microorganisms [14]. The history of each patient should be taken to include or exclude him/her from water rehabilitation. Moreover, patients should be instructed to inform about any health changes due to possible contraindications for a particular form of therapy.

\section{Discussion}

Thanks to its physical properties, the aquatic environment enables to administer rehabilitation in a specific environment different from a gymnasium. The effects of specific stimuli on the entire body and a wide range of exercises allow choosing the most beneficial form of therapy; moreover, patients should exercise with pleasure. The form of rehabilitation can be adjusted to a particular patient and his/her needs, which results in increasingly high awareness regarding the efficacy of hydrotherapy in Poland. Due to growing demands for this range of services, the professional staff has to be more numerous and technical basis improved (adequately equipped rooms, swimming pools, particularly indoor ones, and availability of therapeutic waters). Superficial analysis of these conditions reveals that substantial expenditures are needed to meet these demands. Therefore, despite the unquestionably high efficacy of physiotherapy in the aquatic environment, dynamics of such services does not keep up with the pace of increasing requirements [17].

\section{References}

1. deVierville J. A history of aquatic rehabilitation. [In:] Cole A, Becker B, eds. Comprehensive Aquatic Rehabilitation. 2nd ed. Philadelphia PA: Butterworth -Heinemann; 2004.

2. Becker B., Aquatic Therapy: Scientific foundations and clinical rehabilitation Applications. Am Acad Physical Med Rehab. 2009; 1.

3. Guidelines for safe recreational water environments, Volume 2:Swimming pools and similar environments. World Health Organization; 2000. 
4. Wielka Encyklopedia PWN. Warszawa: PWN; 2004, t. 25.

5. Bonikowska-Zgaińska M, Hydroterapia w warunkach ambulatoryjnych. Rehabilitacja w praktyce. 2008; 3.

6. Poyhonen T, Keskinen KL, Hautala A, Malkia E. Determination of hydrodynamic drag forces and drag coefficients on human leg/foot model during knee exercise. Clin Biomech. 2000; 15.

7. Herold G. Medycyna wewnętrzna. Warszawa : PZWL; 2001.

8. Mróz J., Hydroterapia w leczeniu nadciśnienia tętniczego. Baln Polska. 2004; 46.

9. Olasińska A. Halliwick - koncepcja nauczania pływania osób niepełnosprawnych. Reh Medycz.2002; 4.

10. Lan C, Chen S, Wong M. The effect of Tai Chi on cardiorespiratory function in patients with coronary artery bypass surgery. Med Science and Sports Ex. 1999; 5.
11. Voigt J. Człowiek, który wynalazł Qigong. Journal of Traditional Eastem Health \& Fitness. 2013; 3.

12. Kim SB. O'sullivan DM. Effects of Aqua Aerobic Therapy Exercise for Older Adults on Muscular Strength, Agility and Balance to Prevent Falling during Gait. Journal of Physical Therapy Science. 2013; 8 .

13. Zagórski T. Watsu - nowy wymiar rehabilitacji w wodzie. Rehabilitacja w Praktyce 2008; 3.

14. http://www.physio-pedia.com/Hydrotherapy_ Risk_Management [dostęp 03.11.2014].

\section{Correspondence address:}

Magdalena Pieniążek MA

Collegium Medicum,

Jagiellonian University,

Cracow, Poland 